\title{
The Effect of Photon Flux Density and Lighting Period on Growth, Flowering, Powdery Mildew and Water Relations of Miniature Roses
}

\author{
Leiv M. Mortensen \\ Department of Plant Sciences, The Norwegian University of Life Sciences, Ås, Norway \\ Email: lei-mo@online.no
}

Received 17 March 2014; revised 16 April 2014; accepted 8 May 2014

Copyright (C) 2014 by author and Scientific Research Publishing Inc. This work is licensed under the Creative Commons Attribution International License (CC BY). http://creativecommons.org/licenses/by/4.0/

(c) (i) Open Access

\section{Abstract}

Miniature roses (Rosa sp.) were grown at 100 and $150 \mu \mathrm{mol} \mathrm{m} \mathbf{~}^{-2} \cdot \mathrm{s}^{-1}$ photon flux densities (PFD) with 16, 20 and $24 \mathrm{~h} \cdot \mathrm{day}^{-1}$ lighting periods (LP) in a greenhouse compartment in midwinter at latitude $59^{\circ}$ north. The study included 10 different treatments and six rose cultivars, altogether 900 plants. The 16 and $20 \mathrm{~h}$ LP were applied with or without a dark period of 8 and 4 h.day-1, respectively, by timing the LP in relation to daylight that lasted for $7-8 \mathrm{~h}$. Number of days until flowering decreased with an increase in PFD and in LP up to 24 day $^{-1}$ and was unaffected by the timing of the 16 and $20 \mathrm{~h} \cdot \mathrm{day}^{-1} \mathrm{LP}$. Number of flowers and plant dry weight increased $20 \%$ to $30 \%$ by increasing the PFD. Plant dry weight increased by increasing the LP from 16 to $20 \mathrm{~h} \cdot \mathrm{day}^{-1}$ (about 25\%), but no effect was found with a further increase to $24 \mathrm{~h} \cdot \mathrm{day}^{-1}$. Mean growth rate until flowering increased $30 \%$ to $40 \%$ by increasing the PFD or by increasing the LP from 16 to $20 \mathrm{~h}$

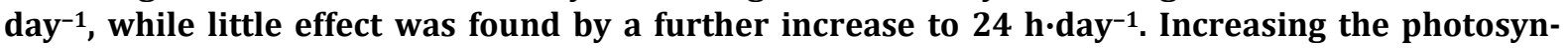
thetic active radiation (PAR) by increasing the LP from 16 to $20 \mathrm{~h} \cdot \mathrm{day}^{-1}$ increased the growth rate more than increasing the PFD did. Three of the cultivars were tested for water loss after the detachment of some leaves. Leaves that had developed without a dark period showed a considerably higher water loss than the treatments that included a dark period of 4 or $8 \mathrm{~h}^{\circ} \mathrm{day}^{-1}$. The keeping quality at indoor conditions, however, was unaffected by the treatment due to sufficient watering. Powdery mildew developed significantly more on plants grown with a dark period of $8 \mathrm{~h}$ as compared with the other treatments. It was concluded that $20 \mathrm{~h} \cdot \mathrm{day}^{-1} \mathrm{LP}$ including a dark period of 4 $\mathrm{h} \cdot \mathrm{day}^{-1}$ and a PFD of at least $150 \mu \mathrm{mol} \cdot \mathrm{m}^{-2} \cdot \mathrm{s}^{-1}$ should be applied to miniature roses during the winter months in order to effectively produce miniature pot roses with a high quality.

\section{Keywords}

Flowering, Growth, Keeping Life, Leaf Water Loss, Lighting Period, Miniature Rose, Photon Flux 


\section{Introduction}

The photosynthetic active radiation (PAR) at high latitudes (about $60^{\circ} \mathrm{N}$ ) in mid-winter is too low (about 1 mol $\mathrm{m}^{-2} \cdot$ day $^{-1}$ ) for an efficient plant production in greenhouses, and therefore supplementary lighting is established as a standard method for plant growth during the winter months. Many practical studies of the light requirements of pot plants have been carried out. However, these studies are seldom published properly and are therefore forgotten. Important questions have been what light level and how many hours per day the supplementary lighting should be applied. Previously, we have reported some studies within this subject [1]-[4]. The effect of lighting period (LP) on plant growth has been found to vary between pot plant species [2] [3]. It is well known that the lighting conditions strongly affect the water relations and keeping quality of cut roses [5] [6]. Typically, continuous lighting has been found to cause loss of the stomata function, resulting in excessive transpiration and decreased vase life at indoor conditions in some cut rose cultivars [6]. Another effect of LP on cut roses was the development of powdery mildew that more or less disappeared when LP reached $24 \mathrm{~h} \cdot \mathrm{day}^{-1}$ [7]. On basis of the results from cut roses and a general need for knowledge about light level and lighting period for miniature pot roses among the growers, a relatively comprehensive study was performed. In the present work the effect of two photon flux densities (PFD) and three lighting periods (LP) on flowering, growth, development of powdery mildew, water relations and keeping quality at indoor conditions were studied. It was also of interest to compare the effect of 16 and $20 \mathrm{~h} \cdot \mathrm{day}^{-1} \mathrm{LP}$ given at daytime with 8 and $4 \mathrm{~h}$ dark periods, respectively, with applying these treatments throughout the whole natural dark period $(7-8 \mathrm{~h}$ day length at this time of the year) causing almost continuous lighting of the plants. Six cultivars were included in the study in order to increase the probability that the results would be representative for miniature roses in general. In order to get a better understanding of the light conditions produced by artificial lighting as compared with daylight, information about the natural light throughout the year at different latitudes in Europe is included.

\section{Materials and Methods}

The miniature rose (Rosa sp.) cultivars Roxy Kordana, Amber, Vanilla, Honney, Optima Red and Absolute Hit were used in the experiment. The plants were grown in standard fertilised peat (Floralux) in $10 \mathrm{~cm}$ pots and were watered daily with a complete nutrient solution. Each pot included five rooted cuttings and the experiment started after the second pinching. The experiment was carried out in a greenhouse compartment at Bioforsk Særheim, Norway (latitude $59^{\circ}$ north). Two levels of PFD $\left(100\right.$ and $\left.150 \mu \mathrm{mol} \cdot \mathrm{m}^{-2} \cdot \mathrm{s}^{-1}\right)$ and $16 \mathrm{~h}$ (from 07:30 to 23:30), $20 \mathrm{~h}$ (from 07:30 to 03:30) and $24 \mathrm{~h} \cdot$ day $^{-1} \mathrm{LP}$ were established. The 16 and $20 \mathrm{~h} \cdot$ day $^{-1} \mathrm{LP}$ were also given without a dark period by providing lighting throughout the natural dark period (16:00 to 08:00). Altogether the study included 10 treatments. High pressure sodium lamps (Philips SON-T) were used. The light was measured by a Lambda LI-185B instrument with a quantum sensor (400 to $700 \mathrm{~nm}$ ). Black curtains were used to avoid light pollution between the different treatments. The experiment was conducted in the period from the middle of December until the beginning of February. The daylight inside the greenhouse was as a daily mean $1.2 \pm 0.7 \mathrm{~mol} \cdot \mathrm{m}^{-2} \cdot \mathrm{day}^{-1}$ during the experiment. The light was measured by the Meteorological Station at Bioforsk Særheim, and the light level was decreased $50 \%$ due to reduction by the greenhouse construction. The air temperature was kept at $20.5^{\circ} \mathrm{C} \pm 0.5^{\circ} \mathrm{C}$, the relative air humidity at $75 \% \pm 5 \%$ and the $\mathrm{CO}_{2}$ concentration at 700 $\pm 100 \mu \mathrm{mol} \cdot \mathrm{mol}^{-1}$. The roses were sprayed with Bonzi (one time with $0.5 \%$ and four times with $1.5 \%$ ) as a commercial practise to produce compact plants. Fifteen pots per cultivar were used in each of the 10 different treatments, totalling 900 pots. At the time of flowering (five open flowers) the number of flowers and flower buds, plant height, plant fresh and dry weight and the development of powdery mildew were recorded on eight plants per treatment and cultivar. The mildew attack was determined visually on a scale from 0 (no visible mildew) to 10 (completely covered by mildew). Seven plants per treatment and cultivar were placed under simulated indoor conditions at $50 \% \mathrm{RH}$ and $7 \mu \mathrm{mol} \cdot \mathrm{m}^{-2} \cdot \mathrm{s}^{-1} \mathrm{PFD}$ and tested for the keeping life (time until no decorative value $=$ wilted flowers). Two groups of five leaves from the upper part of the plants were picked from each treatment and cultivar. The leaves were placed at indoor conditions as already described. The weight immediately after the detachment and after $4.5 \mathrm{~h}$ was measured on each group of leaves. Then the dry weight was de- 
termined on all groups of leaves. The percentage water loss from the leaves during the $4.5 \mathrm{~h}$ was calculated.

The data were analysed using the SAS-GLM procedure (SAS Institute Inc., Cary, USA). Cultivars or leaf group (measurement of water loss) were used as replicates in the analysis. In order to separate the different growth responses between cultivars Duncan's multiple range test was used at $\mathrm{p}=0.05$.

\section{Results}

Time until flowering varied from 48 to 59 days in the different cultivars (Table 1 ). The different growth parameters as well as the keeping quality and amount of powdery mildew also varied between the cultivars. Amber and Absolute Hit were the most mildew-sensitive cultivars. Although the magnitude of the effects of PFD, LP and the timing of the lighting period (DL) on growth, flowering and keeping quality varied to some extent between the cultivars (illustrated by the standard errors) in principle the effects were the same in all cultivars. Therefore, the mean effects on the six cultivars are presented. Increasing the LP from 16 to $24 \mathrm{~h} \cdot \mathrm{day}^{-1} \mathrm{decreased}$ time until flowering from 58 to 53 days at $100 \mu \mathrm{mol} \cdot \mathrm{m}^{-2} \cdot \mathrm{s}^{-1} \mathrm{PFD}$ and from 54 to 45 days at $150 \mu \mathrm{mol} \cdot \mathrm{m}^{-2} \cdot \mathrm{s}^{-1}$ PFD (Table 2). Total number of flowers (buds included) increased $20 \%$ to $30 \%$ by increasing the PFD from 100 to $150 \mu \mathrm{mol} \cdot \mathrm{m}^{-2} \cdot \mathrm{s}^{-1} \mathrm{PFD}$. Increasing the LP from 16 to $20 \mathrm{~h} \cdot$ day $^{-1}$ increased the total number of flowers by 40 to $50 \%$, while a further increase in LP had only a small effect (Table 2). Plant dry weight increased about $25 \%$ when LP increased from 16 to $20 \mathrm{~h} \cdot \mathrm{day}^{-1}$, while a further increase in LP had less effect. Increasing the PFD from 100 to $150 \mu \mathrm{mol} \cdot \mathrm{m}^{-2} \cdot \mathrm{s}^{-1}(50 \%$ increase in PAR) caused a $30 \%$ to $40 \%$ increase in the mean growth rate until flowering. Increasing the DL from 16 to $20 \mathrm{~h} \cdot$ day $^{-1}(25 \%$ increase in PAR) caused an increase in the rate of 30 to $40 \%$, while a further increase to $24 \mathrm{~h} \cdot$ day $^{-1}$ only slightly $(<10 \%)$ increased the rate (Table 2)). The plant height varied between 21 and $26 \mathrm{~cm}$ as a result of a stimulation by increased PFD and LP. The percentage dry weight (of fresh weight) varied between $20 \%$ and $22 \%$ without any systematic differences between the treatments (results not presented). The keeping quality was not significantly affected by the different treatments and varied between 17 and 19 days (Table 2). The powdery mildew attack was the highest at $16 \mathrm{~h} \cdot d a y^{-1} \mathrm{LP}$ with a dark period of eight hours, and it noticeably decreased when continuous light was given by $24 \mathrm{~h} \mathrm{LP}$ or timing the $16 \mathrm{~h}$ and $20 \mathrm{~h} \mathrm{LP}$ in relation to daylight to give continuous light (Table 2). The water loss from detached leaves of three of the cultivars was significantly affected by the lighting period (Table 3). A LP of $24 \mathrm{~h} \cdot$ day $^{-1}$ increased water loss considerably when compared with 16 and $20 \mathrm{~h} \cdot$ day $^{-1} \mathrm{LP}$ with dark periods. If the $16 \mathrm{~h} \cdot \mathrm{day}^{-1} \mathrm{LP}$ was given during the night time, causing a $24 \mathrm{~h}$ photoperiod in combination with daylight, this increased water loss.

\section{Discussion}

Increasing the PAR by $25 \%$ by increasing the LP from 16 to $20 \mathrm{~h} \cdot$ day $^{-1}$ increased the dry weight by about $40 \%$, corresponding to a $1.6 \%$ increase in dry weight per $1 \%$ increase in PAR. This is a considerable increase when compared with the $0.5 \%$ to $1.0 \%$ increase in dry weight per $1 \%$ increase in PAR evidenced in a literature survey and by interviews with growers done by Marcelis et al. [8]. However, increasing the PAR by increasing PFD gave an effect in this range ( $0.8 \%$ dry weight increase per $1 \%$ light increase). This underlines the importance of distributing a particular light dose over a $20 \mathrm{~h} \cdot \mathrm{day}^{-1} \mathrm{LP}$ if possible. Some pot plants are known to benefit from continuous light; for other species a photoperiod of $20 \mathrm{~h}$ gives the maximal effect [2]. Supplementary light to

Table 1. Growth and quality of six different rose cultivars given as means of 10 different treatments. Values followed by different letters are significantly different according to Duncan's multiple range test at $p=0.05$.

\begin{tabular}{|c|c|c|c|c|c|c|c|}
\hline Cultivar & $\begin{array}{l}\text { Days until } \\
\text { flowering }\end{array}$ & $\begin{array}{l}\text { Total no. of } \\
\text { flowers }\end{array}$ & $\begin{array}{l}\text { Plant height } \\
(\mathrm{cm})\end{array}$ & Dry weight (g) & $\%$ dry weight & $\begin{array}{l}\text { Keeping quality } \\
\text { (days) }\end{array}$ & $\begin{array}{l}\text { Mildew infection } \\
\text { (relative values) }\end{array}$ \\
\hline Roxy & $58.7 \mathrm{a}$ & $16 \mathrm{~d}$ & $25.7 \mathrm{a}$ & $16.0 \mathrm{~b}$ & $22.2 \mathrm{a}$ & $12.5 \mathrm{~d}$ & $1.0 \mathrm{~b}$ \\
\hline Amber & $52.7 b$ & $16 \mathrm{~d}$ & $22.9 \mathrm{bc}$ & $14.8 \mathrm{~b}$ & $21.1 \mathrm{~b}$ & $16.0 \mathrm{c}$ & $2.4 \mathrm{a}$ \\
\hline Vanilla & $51.8 \mathrm{bc}$ & $14 d$ & $21.1 \mathrm{~d}$ & $13.4 \mathrm{~b}$ & $19.4 d$ & $23.9 \mathrm{a}$ & $0.3 b$ \\
\hline Honey & $57.8 \mathrm{a}$ & $22 \mathrm{c}$ & $23.9 b$ & $19.7 \mathrm{a}$ & $20.9 \mathrm{bc}$ & $19.0 \mathrm{~b}$ & $0.4 \mathrm{~b}$ \\
\hline Optima Red & $49.4 b c$ & $38 \mathrm{a}$ & $21.3 \mathrm{~cd}$ & $13.5 \mathrm{~b}$ & $20.0 \mathrm{~cd}$ & $19.7 b$ & $0.5 \mathrm{~b}$ \\
\hline Absolute Hit & $48.1 \mathrm{c}$ & $30 b$ & $24.1 \mathrm{ab}$ & $14.5 b$ & $20.3 \mathrm{bcd}$ & $14.1 d$ & $2.0 \mathrm{a}$ \\
\hline
\end{tabular}


Table 2. Significance level of the effect of photon flux density (PFD) and lighting period (LP) on growth, flowering, keeping quality and powdery mildew growth as a mean of six miniature rose cultivars. The $16 \mathrm{~h}$ and $20 \mathrm{LP}$ were given with (D) and without dark periods $(\mathrm{L})$ by timing the lighting in relation to the natural daylight period (DP). Means $( \pm \mathrm{SE}, \mathrm{n}=6)$ of six rose cultivars are given. Significance levels: ns, not significant $(\mathrm{p}>0.05) ;{ }^{*}, \mathrm{p}<0.05 ;{ }^{* *}, \mathrm{p}<0.01 ;$ and ${ }^{* * *}, \mathrm{p}<0.001$.

\begin{tabular}{|c|c|c|c|c|c|c|c|c|}
\hline $\begin{array}{c}\mathrm{LP} \\
\left.\left(\mathrm{h} \cdot \mathrm{day}^{-1}\right)\right)\end{array}$ & $\begin{array}{c}\text { PFD } \\
\left(\mu \mathrm{mol} \cdot \mathrm{m}^{-2} \cdot \mathrm{s}^{-1}\right)\end{array}$ & $\begin{array}{l}\text { Days until } \\
\text { flowering }\end{array}$ & $\begin{array}{l}\text { Total no. of } \\
\text { flowers }\end{array}$ & $\begin{array}{l}\text { Plant height } \\
(\mathrm{cm})\end{array}$ & $\begin{array}{l}\text { Dry weight } \\
\text { (g) }\end{array}$ & $\begin{array}{l}\text { Growth rate } \\
\left(\mathrm{mg}^{-} \text {day }^{-1}\right)\end{array}$ & $\begin{array}{c}\text { Keeping } \\
\text { quality (days) }\end{array}$ & $\begin{array}{l}\text { Mildew } \\
(0-10)\end{array}$ \\
\hline $16 \mathrm{D}$ & 100 & $57.8 \pm 1.8$ & $16 \pm 3$ & $23.0 \pm 0.8$ & $12.3 \pm 0.7$ & $212 \pm 5$ & $17.1 \pm 1.8$ & $2.6 \pm 0.6$ \\
\hline $16 \mathrm{D}$ & 150 & $54.0 \pm 1.8$ & $20 \pm 3$ & $23.4 \pm 1.0$ & $15.0 \pm 1.0$ & $277 \pm 11$ & $16.9 \pm 1.7$ & $2.3 \pm 0.6$ \\
\hline $20 \mathrm{D}$ & 100 & $55.6 \pm 2.3$ & $22 \pm 5$ & $23.1 \pm 1.3$ & $15.2 \pm 1.3$ & $273 \pm 15$ & $17.1 \pm 1.8$ & $1.5 \pm 0.7$ \\
\hline $20 \mathrm{D}$ & 150 & $48.7 \pm 1.9$ & $30 \pm 5$ & $24.1 \pm 0.8$ & $19.0 \pm 1.7$ & $389 \pm 22$ & $18.3 \pm 1.7$ & $0.5 \pm 0.3$ \\
\hline $24 \mathrm{~L}$ & 100 & $52.6 \pm 1.7$ & $25 \pm 5$ & $23.3 \pm 1.0$ & $15.2 \pm 1.3$ & $289 \pm 23$ & $16.6 \pm 1.6$ & $0.8 \pm 0.3$ \\
\hline $24 \mathrm{~L}$ & 150 & $45.0 \pm 1.4$ & $30 \pm 5$ & $25.8 \pm 0.8$ & $18.9 \pm 1.8$ & $418 \pm 28$ & $17.3 \pm 2.0$ & $0.3 \pm 0.2$ \\
\hline $16 \mathrm{~L}$ & 100 & $58.2 \pm 1.9$ & $17 \pm 2$ & $20.8 \pm 0.7$ & $11.8 \pm 0.6$ & $203 \pm 7$ & $17.0 \pm 1.5$ & $0.5 \pm 0.2$ \\
\hline $16 \mathrm{~L}$ & 150 & $56.6 \pm 2.4$ & $19 \pm 3$ & $21.8 \pm 1.0$ & $14.4 \pm 0.7$ & $254 \pm 8$ & $18.6 \pm 2.0$ & $0.4 \pm 0.2$ \\
\hline $20 \mathrm{~L}$ & 100 & $53.9 \pm 1.7$ & $22 \pm 4$ & $22.6 \pm 1.0$ & $13.9 \pm 0.8$ & $258 \pm 14$ & $16.8 \pm 1.7$ & $1.1 \pm 0.5$ \\
\hline $20 \mathrm{~L}$ & 150 & $48.6 \pm 2.1$ & $28 \pm 6$ & $24.0 \pm 0.7$ & $17.6 \pm 1.1$ & $363 \pm 20$ & $19.5 \pm 2.2$ & $0.8 \pm 0.5$ \\
\hline \multicolumn{9}{|c|}{ Significance levels } \\
\hline PFD & & $* * *$ & * & * & $* * *$ & ${ }^{* * *}$ & $\mathrm{~ns}$ & ns \\
\hline LP & & $* * *$ & $*$ & $*$ & $* * *$ & ${ }^{* * *}$ & $\mathrm{~ns}$ & * \\
\hline PFD x LP & & $\mathrm{ns}$ & $\mathrm{ns}$ & $\mathrm{ns}$ & $\mathrm{ns}$ & * & $\mathrm{ns}$ & ns \\
\hline DP & & ns & ns & ns & ns & ns & ns & $* *$ \\
\hline DP x LP & & ns & ns & $\mathrm{ns}$ & $\mathrm{ns}$ & $\mathrm{ns}$ & ns & ** \\
\hline
\end{tabular}

Table 3. Water loss (\%) after $4.5 \mathrm{~h}$ of detached leaves from three rose cultivars grown at different lighting periods (LP) and photon flux densities (PFD). The $16 \mathrm{~h} \mathrm{LP}$ was given with (D) and without (L) dark periods (DP). Means $( \pm \mathrm{SE}, \mathrm{n}=2)$ on cultivar basis, $n=6$ for means of three cultivars).

\begin{tabular}{|c|c|c|c|c|c|}
\hline LP $\left(h \cdot\right.$ day $\left.\left.^{-1}\right)\right)$ & $\operatorname{PFD}\left(\mu \mathrm{mol} \cdot \mathrm{m}^{-2} \cdot \mathrm{s}^{-1}\right)$ & Absolute Hit & Roxy & Vanilla & Means of three $\mathrm{cv}$ \\
\hline $16 \mathrm{D}$ & 100 & $41.0 \pm 3.0$ & $39.0 \pm 2.0$ & $35.5 \pm 1.5$ & $38.5 \pm 1.5$ \\
\hline $16 \mathrm{D}$ & 150 & $46.0 \pm 2.0$ & $35.0 \pm 0.0$ & $31.5 \pm 2.5$ & $37.5 \pm 3.0$ \\
\hline $20 \mathrm{D}$ & 100 & $46.0 \pm 1.0$ & $33.5 \pm 0.5$ & $35.0 \pm 1.0$ & $38.2 \pm 2.6$ \\
\hline $20 \mathrm{D}$ & 150 & $39.5 \pm 0.5$ & $29.5 \pm 0.5$ & $28.0 \pm 1.0$ & $32.3 \pm 2.3$ \\
\hline $24 \mathrm{~L}$ & 100 & $69.5 \pm 0.5$ & $52.0 \pm 5.0$ & $52.0 \pm 6.1$ & $57.8 \pm 4.3$ \\
\hline $24 \mathrm{~L}$ & 150 & $62.0 \pm 0.0$ & $61.0 \pm 2.0$ & $50.0 \pm 3.0$ & $57.6 \pm 2.6$ \\
\hline $16 \mathrm{~L}$ & 100 & $54.5 \pm 0.5$ & $54.5 \pm 3.5$ & $37.5 \pm 1.5$ & $48.8 \pm 3.8$ \\
\hline $16 \mathrm{~L}$ & 150 & $55.0 \pm 2.0$ & $55.0 \pm 3.0$ & $39.5 \pm 0.5$ & $49.8 \pm 3.5$ \\
\hline \multicolumn{6}{|c|}{ Significance levels } \\
\hline PFD & & $\mathrm{ns}$ & ns & $\mathrm{ns}$ & ns \\
\hline LP & & $* * *$ & $* * *$ & $* *$ & $* * *$ \\
\hline $\mathrm{PFD} \times \mathrm{LP}$ & & $*$ & ns & ns & ns \\
\hline DP (with $16 \mathrm{~h} \mathrm{LP}$ ) & & ** & $* *$ & * & $* *$ \\
\hline $\mathrm{PFD} \times \mathrm{DP}$ & & ns & ns & ns & ns \\
\hline
\end{tabular}


miniature roses should be given for $20 \mathrm{~h} \cdot \mathrm{day}^{-1}$ to maximise light use efficiency. The light dose should be given daily in order to avoid growth reduction [9]. A combination of $150 \mu \mathrm{mol} \cdot \mathrm{m}^{-2} \cdot$ day $^{-1}$ during a $20 \mathrm{~h} \cdot$ day $^{-1} \mathrm{LP}$ gives a PAR of $10.8 \mathrm{~mol} \cdot \mathrm{m}^{-2} \cdot \mathrm{day}^{-1}$. If adding daylight, as in the present experiment, a light sum of about $12 \mathrm{~mol} \cdot \mathrm{m}^{-2}$ day $^{-1}$ is recommended for miniature roses at an air temperature of about $20^{\circ} \mathrm{C}$. This is in accordance with previous results with miniature roses [9]. In order to reduce the time until flowering from 45 - 50 days to 30 days, however, the temperature should be increased to about $24^{\circ} \mathrm{C}$ and the PAR should be increased to 15 to 20 $\mathrm{mol} \cdot \mathrm{m}^{-2} \cdot \mathrm{day}^{-1}$ in order to produce plants with many flowers [10]. This is a light integral within the range found to be optimal for a range of ornamental species [11]-[13]. If we compare this PAR with the natural PAR inside a greenhouse (with $60 \%$ transmission) at latitude $59^{\circ}$ north, it appears that supplementary lighting must be given during five months of the year to reach $12 \mathrm{~mol} \cdot \mathrm{m}^{-2} \cdot \mathrm{day}^{-1}$, and it must be given about seven months to achieve 20 $\mathrm{mol} \cdot \mathrm{m}^{-2} \cdot \mathrm{day}^{-1}$ (Figure 1). In Almeria, South Spain, a region with the highest solar radiation in Europe, 12 $\mathrm{mol} \cdot \mathrm{m}^{-2} \cdot \mathrm{day}^{-1}$ is reached throughout the whole year without supplementary lighting in a greenhouse with $60 \%$ transmission (Figure 1). Even in this sunny region of Europe a PAR of $20 \mathrm{~m}^{-2} \cdot$ day $^{-1}$ is reached only in eight months of the year. Although if a sufficient high PAR is obtained, this light is probably much less efficient than expected due to short photoperiods at $37^{\circ}$ north $\left(9\right.$ to $\left.14 \mathrm{~h} \cdot \mathrm{day}^{-1}\right)$ and due to PFD levels that considerably exceed the light saturation point of $400-500 \mu \mathrm{mol} \cdot \mathrm{m}^{-2} \cdot \mathrm{s}^{-1}$ in miniature roses, as well as in other pot plants [10].

A positive effect of increasing the LP to $24 \mathrm{~h} \cdot \mathrm{day}^{-1}$ was the relative decrease in powdery mildew, as has been previously shown with some cut rose cultivars [7]. To some extent this could also be obtained with a shorter LP if it was combined with daylight to give continuous light. The reason for the development of powdery mildew when plants are exposed to a dark period is probably a temperature drop that makes a diurnal temperature variation that stimulates the germination and proliferation of the spores [14]. However, a negative effect of a 24 $\mathrm{h} \cdot$ day $^{-1} \mathrm{LP}$, in addition to decreased light use efficiency, was an increase in water loss from the leaves, indicat-

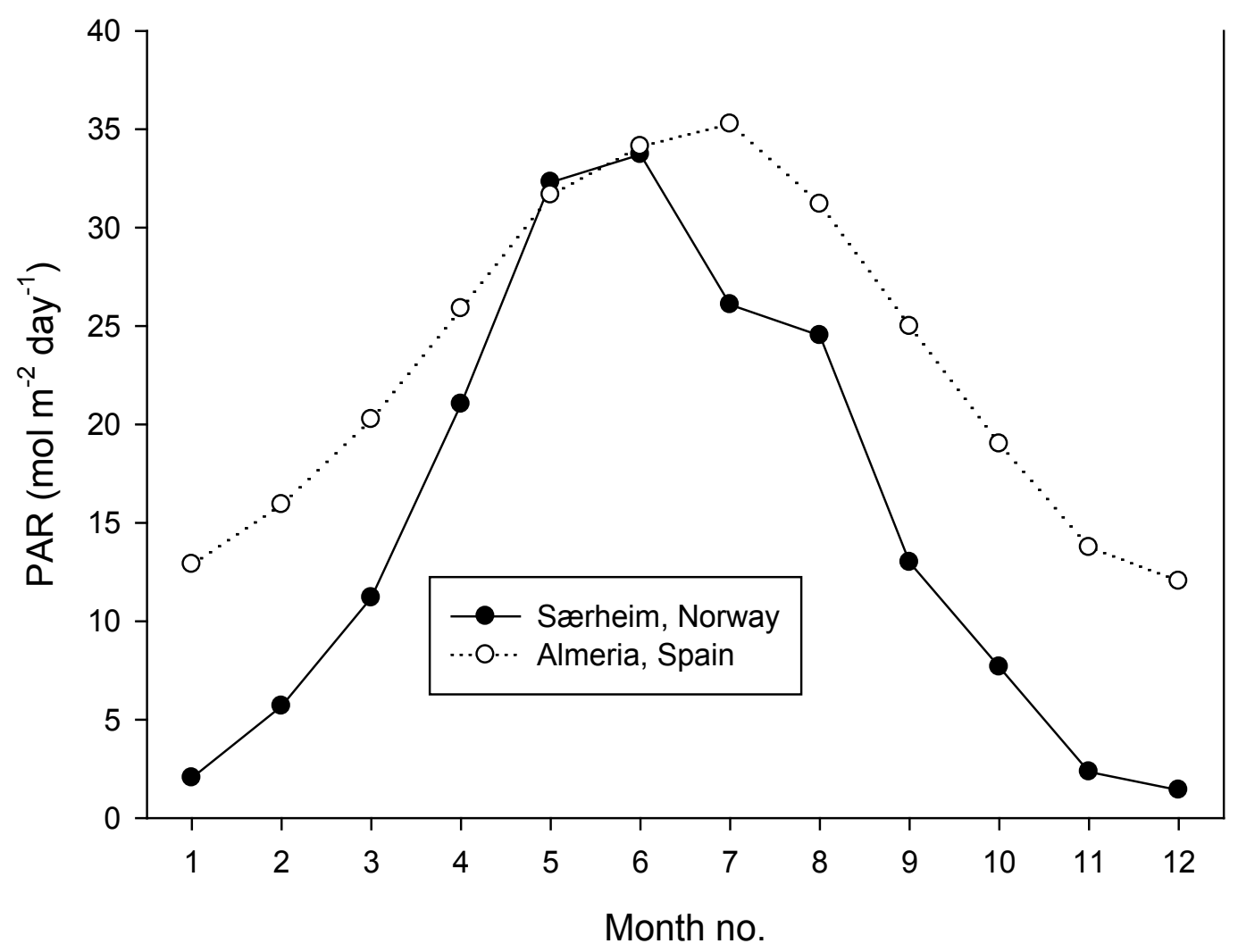

Figure 1. The PAR from January to December at Bioforsk Særheim, Norway (latitude $59^{\circ}$ north (www.bioforsk.no, Agricultural Meteorological service), and in Almeria, Spain (latitude $37^{\circ}$ north, www.pveducation.org, PVCDROM) inside a greenhouse with $60 \%$ light transmission. The values are given as daily means per month and are recalculated from $\mathrm{kWh}$ solar radiation to mol PAR using a conversion factor of $7.9 \mathrm{~mol}$ per $1.0 \mathrm{kWh}$. 
ing reduced stomata closure. This is in accordance with previous results with cut roses, which showed that decreased stomata function caused increased transpiration and flower wilting in indoor conditions [6]. In the present experiment with plants with intact roots this did not cause any reduction in keeping life since the plants were watered frequently. In practice the increased water consumption resulting from reduced stomata closure may cause the pots to dry out and the plants to wilt if they are not frequently watered. It was concluded that 20 $\mathrm{h} \cdot$ day $^{-1} \mathrm{LP}$ including a dark period of $4 \mathrm{~h} \cdot \mathrm{day}^{-1}$ and a PFD of at least $150 \mu \mathrm{mol} \cdot \mathrm{m}^{-2} \cdot \mathrm{s}^{-1}$ should be applied to miniature roses during the winter months in order to effectively produce miniature pot roses with a high quality.

\section{Acknowledgements}

This work was carried out as a part of the project "An energy dynamic Norwegian greenhouse industry" funded by the Norwegian Research Council and Norwegian Growers.

\section{References}

[1] Mortensen, L.M. and Ulsaker, R. (1985) Effect of $\mathrm{CO}_{2}$ Concentration and Light Levels on Growth, Flowering and Photosynthesis of Begonia x hiemalis Fotsch. Scientia Horticulturae, 27, 133-141. http://dx.doi.org/10.1016/0304-4238(85)90063-9

[2] Gislerød, H.R., Eidsten, I.M. and Mortensen, L.M. (1989) The Interaction of Daily Lighting Period and Light Intensity on Growth of Some Greenhouse Plants. Scientia Horticulturae, 38, 295-304. http://dx.doi.org/10.1016/0304-4238(89)90077-0

[3] Mortensen, L.M. and Grimstad, S.O. (1990) The Effect of Lighting Period and Photon Flux Density on Growth of Six Foliage Plants. Scientia Horticulturae, 41, 337-342. http://dx.doi.org/10.1016/0304-4238(90)90114-T

[4] Mortensen, L.M. (1991) Effect of Temperature, Light and $\mathrm{CO}_{2}$ Level on Growth and Flowering of Miniature Roses. Norwegian Journal of Agricultural Sciences, 5, 295-300.

[5] Mortensen, L.M. and Fjeld, T. (1998) Effects of Air Humidity, Lighting Period and Lamp Type on Growth and Vase Life of Roses. Scientia Horticulturae, 73, 229-237. http://dx.doi.org/10.1016/S0304-4238(98)00075-2

[6] Mortensen, L.M. and Gislerød, H.R. (1999) Influence of Air Humidity and Lighting Period on Growth, Vase Life and Water Relations of 14 Rose Cultivars. Scientia Horticulturae, 82, 289-298. http://dx.doi.org/10.1016/S0304-4238(99)00062-X

[7] Mortensen, L.M., Pettersen, R.I. and Gislerød, H.R. (2007) Air Humidity Variation and Control of Vase Life and Powdery Mildew in Cut Roses under Continuous Lighting. European Journal of Horticultural Science, 72, 255-259.

[8] Marcelis, L.F.M., Brockhuijsen, A.G.M., Meinen, E., Nijs, E.M.F.M. and Raaphorst, M.G.M. (2006) Quantification of the Growth Response to Light Quantity of Greenhouse Crops. Acta Horticulturae, 711, 97-103.

[9] Mortensen, L.M. (2004) Growth and Light Utilization of Pot Plants at Variable Day-to-Day Irradiances. Journal of Horticultural Science, 69, 89-95.

[10] Mortensen, L.M. (2014) The Effect of Wide-Range Photosynthetic Active Radiations on Photosynthesis, Growth and Flowering of Rosa sp. and Kalanchoe blossfeldiana. American Journal of Plant Science, 5, 1489-1498.

[11] Warner, R.M. and Erwin, J.E. (2005) Prolonged High Temperature Exposure and Daily Light Integral Impact Growth and Flowering of Five Herbaceous Ornamental Species. Journal of the American Society for Horticultural Science, 130, 283-288.

[12] Moccaldi, L.A. and Runkle, E.S. (2007) Modelling the Effect of Temperature and Photosynthetic Daily Light Integral on Growth and Flowering of Salvia splendens and Tagetes patula. Journal of the American Society for Horticultural Science, 132, 283-288.

[13] Blanchard, M.G., Runkle, E.S. and Fisher, P.R. (2011) Modeling Plant Morphology and Development of Petunia in Response to Temperature and Photosynthetic Light Integral. Scientia Horticulturae, 129, 313-320. http://dx.doi.org/10.1016/j.scienta.2011.03.044

[14] Mortensen, L.M., Toppe, B. and Gislerød, H.R. (2006) Influence of Carbon Dioxide Concentration and Diurnal Temperature Variation on Growth, Powdery Mildew and Quality of Cut Roses. European Journal of Horticultural Science, 71, 217-221. 